\title{
Habitat comparison of Mideopsis orbicularis (O. F. Müller, 1776) and M. crassipes Soar, 1904 (Acari: Hydrachnidia) in the Krąpiel River
}

\author{
Andrzej Zawal ${ }^{1, *}$, Przemysław Śmietana ${ }^{2}$, Edyta Stępieńn ${ }^{3}$, Vladimir Pešićc \\ Magdalena Klosowska ${ }^{1}$, Grzegorz Michoński ${ }^{1}$, Aleksandra Bańkowska ${ }^{1}$, Piotr \\ Dąbkowski' ${ }^{1}$ \& Robert Stryjecki ${ }^{5}$
}

\footnotetext{
1 Department of Invertebrate Zoology \& Limnology, University of Szczecin, 71-415 Szczecin, Wąska 13, Poland.

2 Deparment of Ecology \& Environmental Protection, University of Szczecin, 71-415 Szczecin, Wąska 13, Poland.

3 Department of Plant Taxonomy and Phytogeography, University of Szczecin, 71-415 Szczecin, Wąska 13, Poland.

${ }^{4}$ Department of Biology, University of Montenegro, Cetinjski put b.b., 81000 Podgorica, Montenegro.

5 Department of Zoology, Animal Ecology and Wildlife Management, University of Life Sciences in Lublin, Akademicka 13, 20-950 Lublin, Poland.

* Corresponding author: Andrzej Zawal, e-mail: zawal@univ.szczecin.pl
}

\begin{abstract}
Ecological studies of water mites have a very long tradition. However, no explicit data have been obtained to date with regard to specific ecological parameters defining autoecological values for particular species, and therefore such values have not been compared between closely related species. The present study is an attempt at making such comparisons between two closely related species: Mideopsis orbicularis and Mideopsis crassipes. Both species are psammophilous; $M$. orbicularis prefers stagnant waters, while $M$. crassipes prefers running waters. The research was conducted during 2010 in 89 localities distributed along the Krappiel River and in water reservoirs found in its valley. The two species were collected solely in the river, where they were found in 26 localities and only these localities were analyzed. Until now M. crassipes was characterized as a species preferring rather fast-flowing habitats, and $M$. orbicularis as preferring slow water habitats, i.e. isolated still-water bodies. In this study both species preferred slow flow water habitats: $77.5 \%$ (225 individuals) of all M. orbicularis specimens and $67.3 \%$ (318 individuals) of all $M$. crassipes specimens were collected in isolated still-water bodies. The only correlations identified between water mite occurrence and water quality were the positive one between the abundance of $M$. orbicularis and water temperature, the negative one between the abundance of this species and $\mathrm{BOD}_{5}$. There were also some correlations with substrate, including the positive correlation between occurrence of $M$. crassipes and sandy bottom. M. orbicularis was also encountered on organic bottoms and among water plants.
\end{abstract}

KEY WORDS: water mites, bottom, $\mathrm{BOD}_{5}$, oxygen, temperature

\section{INTRODUCTION}

Studies of water mite ecology have a long tradition and thus the ecological characteristics of most species have already been established. A comparatively large number of publications have been devoted to the association between vertical oxygen distribution and the presence of water mites within a lake basin (VIETS, 1930, 1931; PIECZYŃSKI, 1959; KOWALIK 1973, 1977, 1978, 1984; Meyer \& SCHWOerbel, 1981; ZaWAL,
2007; ZAWAL \& STĘPIEŃ, 2007). CiCHOCKA's (1998) study showed correlations between hydrochemical parameters and the occurrence of water mites in peat bogs, while works of several other authors (CICOLANI \& Di SABATINO, 1991; GereCKe \& SCHWOERBEL, 1991; Di SABATINO et al., 2000; STUR et al., 2005; САMACHO et al., 2006; VAN HAAREN \& TEMPELMAN, 2009; MARTIN et al. 2010; BOTTAZZI et al., 2011; STOCH et al., 2011) investigated the connection between the presence of water mites and other 
invertebrates, and physico-chemical parameters of lotic waters. The present paper compares the habitat occurrence of two closely related species, Mideopsis orbicularis and Mideopsis crassipes, inhabiting the valley of a rather small lowland river: the Krąpiel. According to data from literature (VIETS, 1936; BIESIADKA \& KOWALIK, 1979; GERECKE, 2002), both of these species show preference for sandy bottoms, but the first of them inhabits mainly lentic waters, while the latter prefers lotic waters. However, under certain conditions the species co-occur in the same habitats. This refers mainly to small and medium-sized lowland rivers. The Krąpiel River, where studies on macrobenthos distribution, water mite fertility and the impact of river dredging on the fauna of invertebrates and vegetation have been conducted (KESZKA \& RACZYŃSKI, 2004; RACZYŃSKA \& MACHULA, 2006; ZAWAL, 2009; DIERZGOWSKA \& ZAWAL, 2010; BUCZYŃSKI et al., 2011; KŁOSOWSKA et al., 2011; KURZĄTKOWSKA \& ZAWAL, 2011; SZLAUER-ŁUKASZEWSKA \& ZAWAL, 2013, STĘPIEŃ et al., 2015, ZAWAL et al., 2015) was an excellent site for checking patterns of occurrence of the two species in various habitats in relationship to physico-chemical parameters of water and the bottom structure. It was hypothesized that main parameters affecting the occurrence of the two species include flow velocity, sediment type, degree of vegetation coverage of the bottom and oxygen content. It was assumed that $M$. crassipes would occur in habitats characterized by a more rapid water flow and higher oxygen content.

\section{MATERIALS AND METHODS}

The study was based on material collected for the purpose of a project examining the effect of landscape structure on the distribution of selected groups of aquatic invertebrates in a small lowland river. Fieldwork was conducted from May until October, 2010. The research covered the whole length of the river where 89 research sites were established in 13 locations (Fig. 1), distributed in such a way as to cover all habitat types in which water mites occurred. Samples were collected from both lotic and lentic waters with a triangular hand net. Each sampling consisted of 10 energetic sweeps and covered an area of ca. $0.5 \mathrm{~m}^{2}$. Three subsamples were collected from each site for the purpose of variability analyses. Further analysis focused on those sites where at least one of the two mite species was encountered at least once. In total, 546 samples were collected from 26 sites situated solely in lotic waters.

The water parameters: temperature, $\mathrm{pH}$, electrolytic conductivity and dissolved oxygen content were measured with an Elmetron CX-

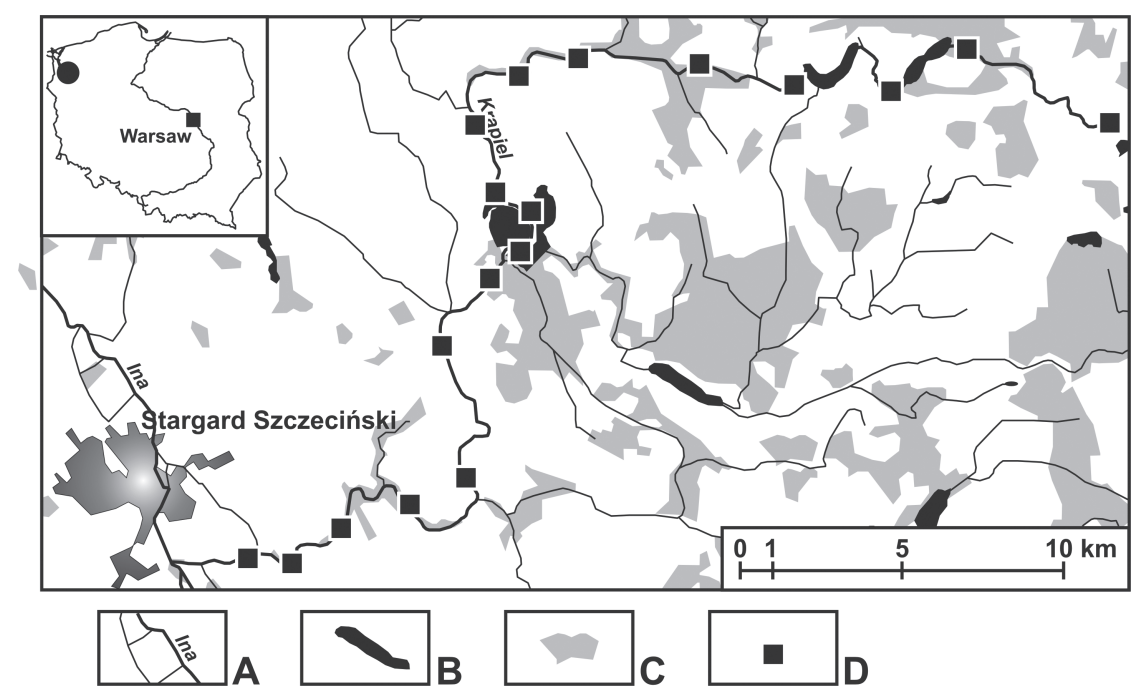

Fig. 1. - Location of the research sites: A - rivers, B - lakes and fish ponds, C - forests, D - research sites. 
Table 1

Correlations between number of specimens and water parameters.

\begin{tabular}{|l|c|c|c|c|c|c|c|c|c|c|c|c|}
\hline Parameters & \multicolumn{10}{|c|}{ Spearman's correlations. In bold significance; $\mathrm{p}<0.05$} \\
\hline & $\mathrm{O}_{2}$ & $\mathrm{pH}$ & Temp. & Cond. & $\mathrm{NH}_{4}$ & $\mathrm{NO}_{3}$ & $\mathrm{PO}_{3}$ & $\mathrm{Fe}$ & Turb. & Hard & $\mathrm{BOD}_{5}$ & Curr \\
\hline M. orbicularis & 0,089 & 0,076 & $\mathbf{0 , 2 2 4}$ & $-0,143$ & $-0,034$ & 0,092 & $-0,023$ & 0,104 & $-0,071$ & 0,082 & $\mathbf{- 0 , 3 4}$ & $-0,069$ \\
\hline M. crassipes & 0,156 & 0,123 & 0,074 & 0,175 & $-0,045$ & 0,059 & $-0,096$ & 0,057 & 0,12 & 0,103 & 0,067 & 0,137 \\
\hline
\end{tabular}

401 multiparametric sampling probe; water flow using a SonTek acoustic Flow Tracker flowmeter; $\mathrm{BOD}_{5}$ by Winkler's method, and $\mathrm{NH}_{4}, \mathrm{NO}_{3}$, $\mathrm{PO}_{3}$, Fe, turbidity, hardness with the help of Slandi LF205 photometer. Three measurements were performed every time and the median was used for further analyses. The following statistical methods were used for data analysis: the chi-squared test - to identify differences in the sex ratio and preferences regarding bottom granularity; Spearman's correlation to identify the correlation between the abundance of species and physico-chemical parameters of water; discrimination analysis and Mann-Whitney U test to identify the correlation between species distribution and physico-chemical parameters of water; and the non-parametric ANOVA Kruskal-Wallis test to identify seasonal changes in a number of specimens. All analyzes were performed using Statistica 9.0 PL.

\section{RESULTS}

Water mites representing the genus Mideopsis were found in 26 of the 89 sites sampled; the presence of $M$. orbicularis was recorded in 23 sites, the presence of $M$. crassipes in 24 sites, and 22 sites were inhabited by both species simultaneously. All sites were associated with the river bed (Fig. 1). The sites situated in the river current were inhabited by two species much more frequently (18 sites) and at higher abundance than those situated in isolated stillwater bodies ( 8 sites) the differences were not statistically significant. In total, 762 specimens were of mites collected: 290 individuals of $M$. orbicularis and 472 individuals of M. crassipes. Statistically significant correlations were found between abundance $M$. orbicularis and temperature (positive correlation) and $\mathrm{BOD}_{5}$ (negative correlation) (Table 1).

$\mathrm{BOD}_{5}$ was the only parameter with discriminative value among all hydrochemical factors considered (Wilks' Lambda distribution: 0.91670; approximate F-distribution: $(1.80)=$ $7.269 ; \mathrm{p}<0.008)$ and displayed a statistically significant difference between the species (Mann-Whitney's U test: $Z=-2.246 ; p=0.025$ ), revealing a much higher tolerance in the case of M. crassipes.

M. crassipes displayed a significant positive relationship with a mineral bottom (MannWhitney's $U$ test: $Z=2.635 ; p=0.008$ ) and was more common in habitats without plants $(Z=$ -2.145; $\mathrm{p}=0.031)$. Chi square tests revealed statistically significant differences in relation to the structure of the bottom where each species occurred $\left(\mathrm{Chi}^{2}=228,239 \mathrm{df}=8 \mathrm{p}<0.0001\right)$. Furthermore, M. crassipes appeared to prefer bottoms characterized by larger grain sizes than M. orbicularis (Fig. 2).

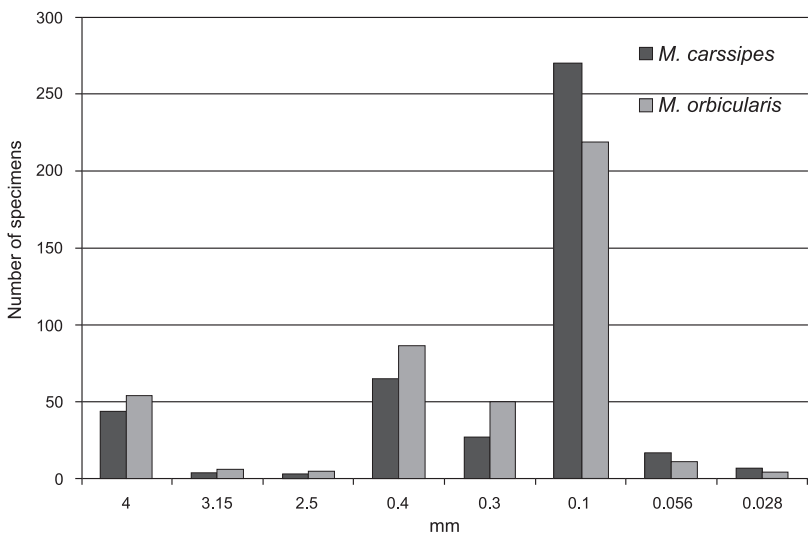

Fig. 2. - The occurrence of the species depending of the size of the ground grain. 


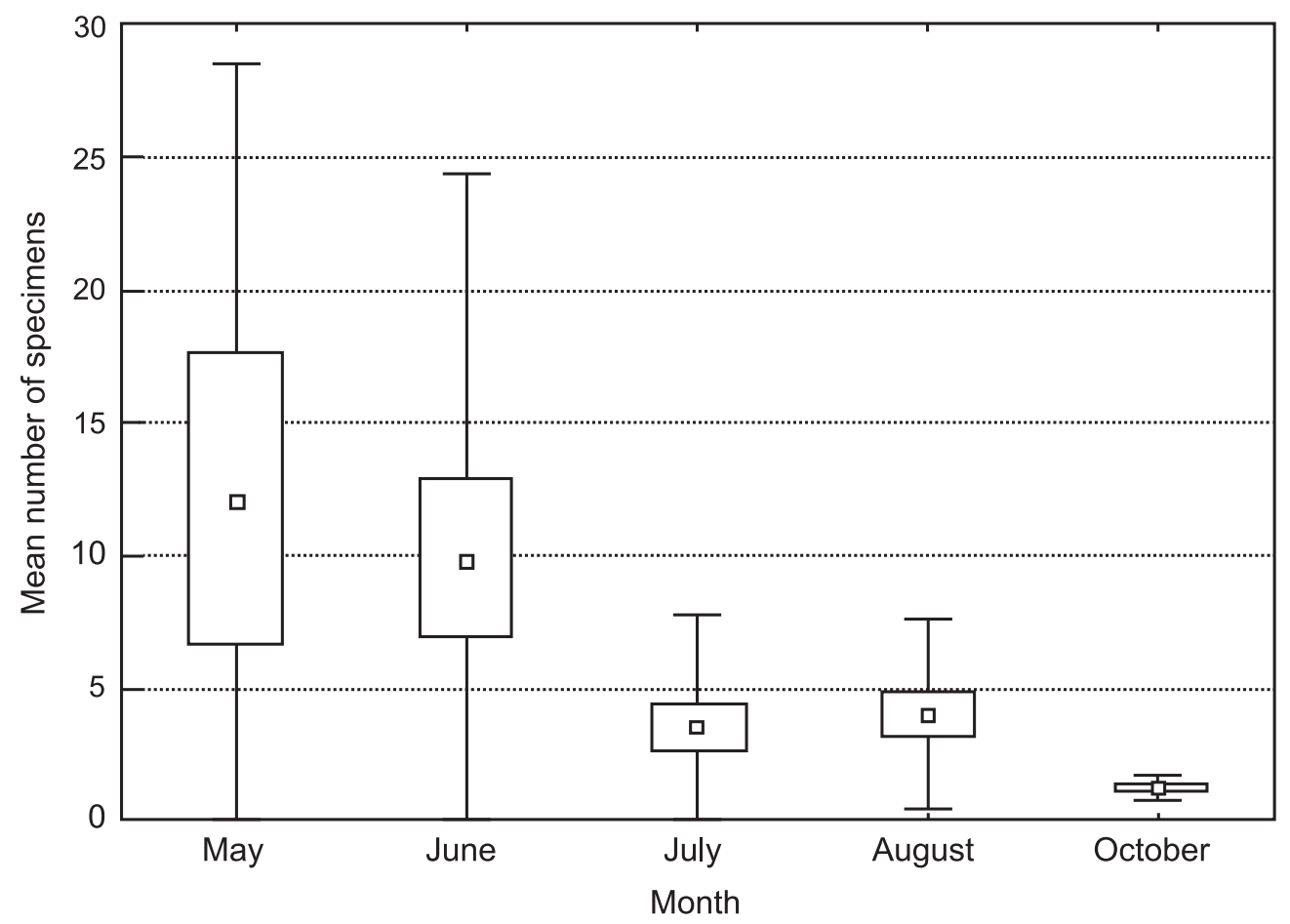

Fig. 3. - Changes of number of specimens of M. orbicularis during the whole research period.

Both species showed largest numbers of individuals present in early summer and a decline through to autumn (Figs 3-4). Results of the Kruskal-Wallis test showed that those changes were statistically significant for $M$. crassipes $(\mathrm{H}$
$(4, \mathrm{~N}=84)=11.497 \mathrm{p}=.0215))$, but not for $M$. orbicularis $(\mathrm{H}(4, \mathrm{~N}=84)=7.759 \mathrm{p}=0.101))$. In the case of $M$. orbicularis the lack of significance may be associated with high type II error (low $\mathrm{N}$, the power of the test).

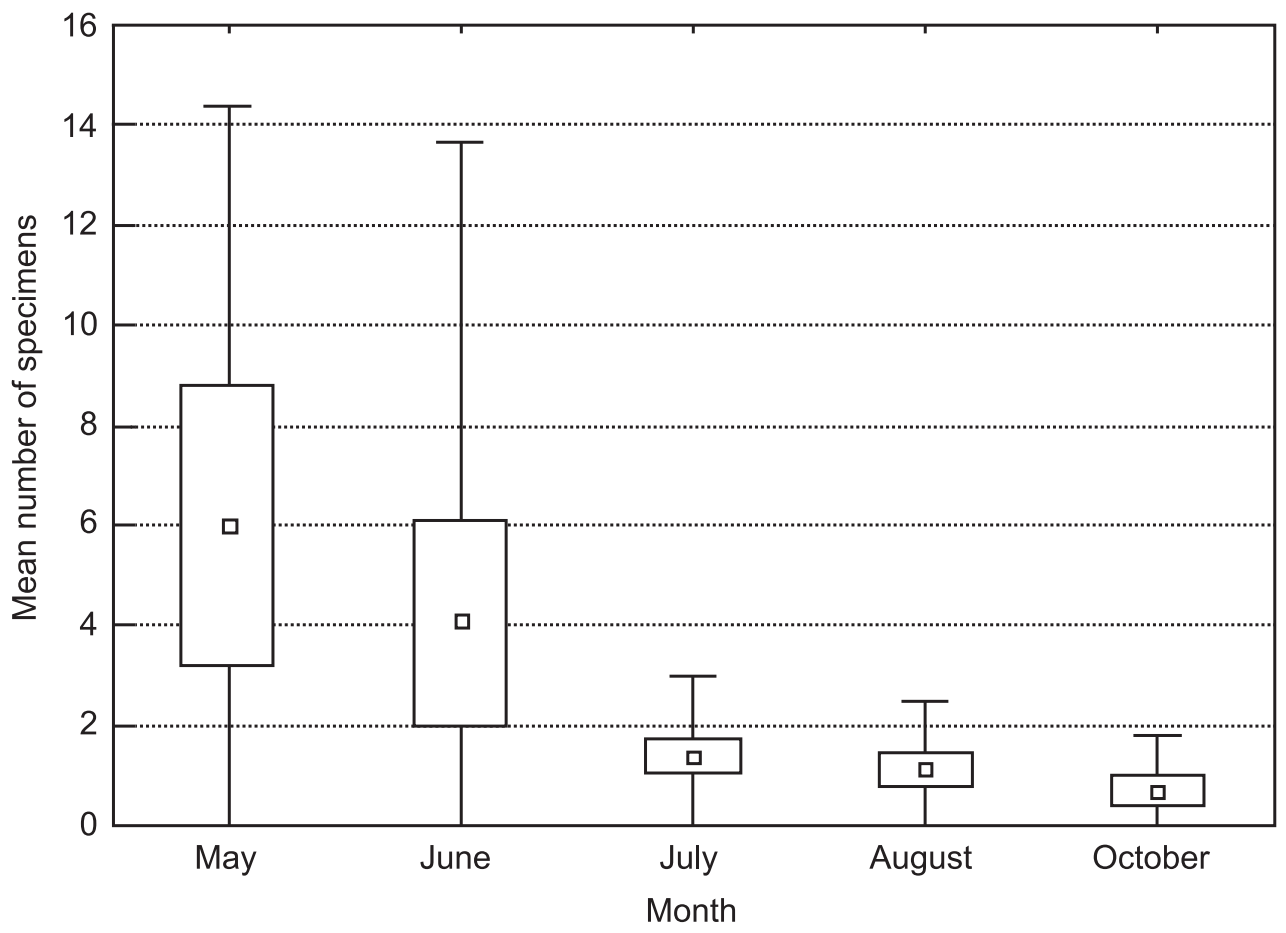

Fig. 4. - Changes of number of specimens of M. crassipes during the whole research period. 


\section{DISCUSSION}

Both $M$. orbicularis and M. crassipes show preference for sandy bottoms (VIETS, 1936; BIESIADKA \& KOWALIK, 1979; MARTIN, 1997) and both of them prey on the Cladocera and larvae of the Diptera, and parasitise the Chironomidae (MARTIN, 2008). So far, the first species has been found mostly in lentic waters (BIESIADKA, 1972; KowaliK, 1984; BAGGE \& MERILÄINEN, 1985; ZAWAL 1992; CICHOCKA, 1998), although it has also occasionally been recorded in lotic waters (CICHOCKA, 1996; STRYJECKI, 2002; BIESIADKA et al., 2004; ZAWAL 2006). As for the latter species, it is a typically rheophilous one (CICHOCKA, 1996; STRYJECKI, 2002; BIESIADKA et al., 2004). In the area studied, both species occurred exclusively in river habitats, avoiding lentic water bodies in the river valley. Similar results were obtained by BIESIADKA et al. (2004). This is due to the character of the valley water bodies, which are very eutrophic and overgrown, and have bottoms covered with a thick layer of mud. The analysis of data from literature (CICHOCKA, 1996; STRYJECKI, 2002; BIESIADKA et al., 2004; ZAWAL 2006), and results of the present study, show that $M$. crassipes is a typically rheophilous species, preferring rather fast-flowing rivers, while $M$. orbicularis is distributed over two habitat types: slow-flowing rivers and lentic waters, with a tendency to prefer the latter. The reason more flowing sites were occupied by the two species in comparison to sites in isolated still-water bodies was certainly due to the fact that the latter sites were definitely less numerous and preferences of the species. M. crassipes occupied the two habitats in approximately equal abundance while $M$. orbicularis was more abundant in isolated still-water bodies.

It is interesting to observe an almost total lack of correlation between the investigated physicochemical parameters of water and the abundance of the studied species. Such correlations have been identified for some water mite species and other invertebrates inhabiting lotic waters (Cicolani \& Di SABATino, 1991; Gerecke
\& Schwoerbel, 1991; Di SABAtino et al., 2000; CAMACHO et al., 2006; BotTAZZI et al., 2011) and most frequently were connected with low temperature, high oxygen content and water pH (KowALIK, 1978, 1984; CiCHOCKA, 1998; ZAWAL, 2007; ZAWAL \& STĘPIEŃ, 2007). The only correlations identified in our study were the positive one between the abundance of $M$. orbicularis and water temperature and the negative one between the abundance of this species and $\mathrm{BOD}_{5}$. This correlation confirmed the more eurythermic character of $M$. orbicularis, reflecting its occurrence in standing waters. The effect of other parameters on its occurrence was probably limited to an indirect effect on $M$. orbicularis through influencing the amount of oxygen. As water turbulence in the river guarantees a constant supply of oxygen, the remaining physico-chemical parameters of the water can be considered to have a negligible effect on the oxygen content in the water. This, of course, applies to rivers that are relatively clean. In polluted rivers decomposition processes consume oxygen, leading to a reduction in the number of water mite species. (CICOLANI \& DI SABATINO, 1991; Gerecke \& Schwoerbel, 1991).

It is believed that both species are associated with a sandy bottom, but our data clearly confirmed this correlation only in the case of $M$. crassipes. M. orbicularis was also encountered in the sites with organic bottoms and among water plants. According to data from previous studies (BIESIADKA, 1972; KowAliK, 1984; BAGGE \& MERILÄINEN, 1985; ZAWAL, 1992; CICHOCKA, 1994), M. orbicularis inhabiting lakes prefers sandy bottoms, but in rivers it also inhabits sites where organics are present and sites that are overgrown with plants (CICHOCKA, 1996; BIESIADKA et al., 2004). As for M. crassipes, it has been encountered almost solely over mineral bottoms, whether it was a sandy bottom or one covered with sand and pebbles, and sometimes also on bottoms covered by the plant periphyton (СicHOCKA, 1996; BIESIADKA et al., 2004). 
There appeared to be some differences between the two species in the study area in terms of the grain sizes of the bottom, albeit the species co-occurred at most sites. $M$. crassipes was associated with more fine-grained bottoms than M. orbicularis. This contrasts with previous classification of $M$. orbicularis as a typically psammophilous species (CICHOCKA, 1996; BIESIADKA et al., 2004). GERECKE (2002) and suggests that $M$. orbicularis is a lenitobiont species, and its presence in rivers is associated with the presence of detritus in the substrate. The current research showed that both species preferred the mineral substrate, although the habitats where $M$. orbicularis dominated were characterized by a slightly higher detritus content. It seems that the psammophilous character of $M$. orbicularis is clearly stronger in stagnant water, which is probably associated with a higher amount of oxygen present on the substrate. However, in the lotic waters this species has a slightly wider range of occurrence and may also occur on gravelly bottoms.

Summing up the above characteristics, it may be stated that $M$. crassipes is a species much more closely associated with lotic water habitats than M. orbicularis and in rivers it prefers habitats that are closer to the river current.

\section{ACKNOWLEDGEMENTS}

Financial support was provided by the Ministry of Science and Higher Education no. N305 222537.

\section{REFERENCES}

BAGGe P \& MERILÄINEN JJ (1985). The occurrence of water mites (Acari: Hydrachnellae) in the estuary of the River Kyrönjoki (Bothnian Bay). Ann. Zool. Fenn., 22: 123-127.

BIESIADKA E (1972). Wodopójki (Hydracarina) Wielkopolskiego Parku Narodowego. Prace monogr. Przyr. Wielkop. Parku Nar., 5: 1-103.
BIESIADKA E \& KowALIK W (1979). A new species of Mideopsis Neuman (Hydrachnellae, Acari) from Poland. Bull. Acad. Pol. Sci., Cl. II, 26(10): 695-702.

BiESIADKA E, CichockA M \& Moroz MD (2004). Water mites (Hydrachnidia) from the Neman River (Belarus), some of its tributaries and riverine reservoirs. Fragmenta faunistica, 47: 143-164.

BUCZYŃSKI P, PRZEWOŹNY M, ZAWAL A \& ZGIERSKA M (2011). On the occurrence of Potamophilus acuminatus (Fabricius, 1772) (Coleoptera: Elmidae) in Poland. Baltic J. Coleopterol., 11: 4556.

Bottazzi E, Bruno MC, Pieri V, Di Sabatino A, Silveri L, Carolli M \& Rossetti G (2011). Spatial and seasonal distribution of invertebrates in Northern Apennine rheocrene springs. In: Cantonati M, Gerecke R, Jüttner I \& Cox EJ (eds), Springs: neglected key habitats for biodiversity conservation: 77-92. J. Limnol., 70 (Suppl. 1), http://dx.doi.org/10.3274/JL11-70-S1-05.

CAMACHO AI, VALDECASAS AG, RODRíGUEZ J, CUEZVA S, LARIO J \& SÁNCHEZ-MORAL S (2006). Habitat constraints in epikarstic waters of the Iberian Peninsula cave system. Ann. Limnol. - Int. J. Lim. 42(2): 127-140. http://dx.doi.org/10.1051/ limn/2006009

CicHOCKA M (1996). Wodopójki (Hydracarina) rzeki Pasłęki. Fragm. Faun., 39(14): 179-205.

СıchockA M (1998). Wodopójki (Hydracarina) torfowisk Pojezierza Mazurskiego. Studium faunistyczno-ekologiczne. Studies and materials of WSP Olsztyn, Olsztyn.

Cicolani B \& Di Sabatino A (1991). Sensitivity of water mites to water pollution. In: Dusbàbek F \& Bukva V (eds), Modern Acarology. Akademia, Prague and SPB Academic Publishing, The Hague, Vol. 1: 465-475

Di Sabatino A, Gerecke R \& Martin P (2000). The biology and ecology of lotic water mites (Hydrachnidia). Freshwater Biol. 44: 47-62.

DZIERZGOWSKA K \& ZAWAL A (2010). Hydrodroma pilosa BESSELING, 1940 and Limnesia undulatoides DAVIDS, 1997 (ACARI, HYDRACHNIDIA) - New records from Poland. Natura Montenegrina, 9 (3): 451-455.

GERECKE R (2002). The water mites (Acari, Hydrachnidia) of a little disturb forest stream in southwest Germany - a study on seasonality and habitat preference, with remarks on diversity 
patterns in different geographical areas. In: BERNini F, NANNELli R, NUZZACI G \& DE LILlo E (eds), Acarid Phylogeny and Evolution. Adaptations in mites and ticks. Kluwer Academic Publishers: 60-89.

GERECKE R \& SCHWOERBEL J (1991). Water quality and water mites (Acari, Actinedida) in the Upper Danube region, 1959-1984. In: Dusbàbek F \& Bukva V (eds), Modern Acarology. Akademia, Prague and SPB Academic Publishing, The Hague, Vol. 1: 483-491.

KESZKA S \& RACZYŃSKI M (2004). Morphological characteristic of dace Leuciscus leuciscus (L.) from Krąpiel river (N-W Poland). In: SPURNY P (ed.), VIII Czech Ichtiological Conference. Procedings of the International Conference. Brno: 48-52.

KŁOSOWSKA M, BAŃKOWSKA A \& ZAWAL A (2011). Składanie jaj przez niektóre gatunki wodopójek (Hydrachnidia) z rzeki Krąpieli i jej zbiorników dolinnych. Ogólnopolska Konferencja „Zwierzęta w życiu człowieka" oraz XX Jubileuszowy Zjazd Polskiego Towarzystwa Zoologicznego: 60-65.

KowaliK W (1973). Wodopójki (Hydracarina) Jezior Sosnowickich na Pojezierzu ŁęczyńskoWłodawskim. Ann. UMCS, C, 28(27): 331-351.

KOWALIK W (1977). Występowanie i rozmieszczenie wodopójek (Hydracarina) w strefie przydennej jeziora Piaseczno. Ann. UMCS, C, 32(25): 323344.

KOWALIK W (1978). Występowanie wodopójek (Hydracarina) w jeziorach o różnej trofii na Pojezierzu Łęczyńsko-Włodawskim. Ann. UMCS, C, 33(32): 443-468.

KowALIK W (1984). Studia faunistyczno-ekologiczne nad wodopójkami (Hydracarina) południowowschodniej Polski. Wydawnictwo AR w Lublinie, Rozprawy Naukowe, Lublin.

KuRZĄTKOWSKA A \& ZAWAL A (2011). Sigara dorsalis (Leach, 1817) (Heteroptera: Corixidae). A new species in Poland and changes in its eastern range extension. Zoologica Poloniae 56: 5-10.

MARTIN P (1997). Zur Faunistik und Substratpräferenz der Wassermilben (Hydrachnidia, Acari) zweier durch feine mineralische Substrate geprägten Bäche in Schleswig-Holstein. Faun. -Ökol. Mitt., 7: 221-237.

MARTIN P (2008). Wassermilben (Hydrachnidia, Acari) und Insekten: Ein Überblick über eine selten betrachtete Beziehung. Entomologie heute, 20: 45-75.
MARTIN P, DABERT M \& DABERT J (2010). Molecular evidence for species separation in the water mite Hygrobates nigromaculatus Lebert, 1879 (Acari, Hydrachnidia): evolutionary consequences of the loss of larval parasitism. Aquatic Sciences 72 (3): 347-360. http://dx.doi.org/10.1007/s00027-0100135-x

MEYer E \& SCHWOERBEL J (1981). Untersuchungen zur Phänologie der Wassermilben (Hydracarina) des Mindelsees. Arch. Hydrobiol. (Suppl.) 59(2/3): 192-251.

PIECZYŃSKI E (1959). Wodopójki (Hydracarina) niektórych środowisk litoralowych jeziora Tajty oraz innych jezior mazurskich. Ekol. Pol. A, 7(5): 169-198.

RACZYŃSKA M\& MACHULA S (2006). Oddziaływanie stawów karpiowych na jakość wód rzeki Krąpiel (Pomorze Zachodnie). Infrastruktura i Ekologia Terenów Wiejskich, 4: 141-149.

STĘPIEŃ E, ZAWAL A, BUCZYŃSKA E \& BUCZYŃSKI $P$ (2015). Changes in the vegetation of a small lowland river valley (Krąpiel, NW Poland) after dredging. Acta Biologica, 22: 128-153.

Stoch F, Gerecke R, Pieri V, Rossetti G \& SAMBUGAR B (2011). Exploring species distribution of spring meiofauna (Annelida, Acari, Crustacea) in the south-eastern Alps. In: Cantonati M, Gerecke R, Jüttner I \& Cox EJ (eds), Springs: neglected key habitats for biodiversity conservation: 65-76. J. Limnol., 70(Suppl. 1), http://dx.doi.org/10.3274/JL11-70-S1-05

STRYJECKI R (2002). The impact of human activity on the water mite fauna (Acari, Hydrachnidia) of the „Lasy Janowskie” Landscape Park (South-Eastern Poland). In: BERnini F, NANNELli R, NuZZACI G \& DE Lillo E (eds), Acarid Phylogeny and Evolution. Adaptations in mites and ticks. Kluwer Academic Publishers: 113-119.

StUR E, MARTin P \& EKREM T (2005). Non-biting midges as hosts for water mite larvae in spring habitats in Luxembourg. Ann. Limnol. - Int. J. Lim., 41(4): 225-236. http://dx.doi.org/10.1051/ $\operatorname{limn} / 2005015$

SZLAUER-ŁUKASZEWSKA A \& ZAWAL A (2014). The impact of river dredging on ostracod assemblages in the Krapiel River (NW Poland), 185: 295-305. http://dx.doi.org/10.1127/fal/2014/0620

VAn HaARen T \& Tempelman D (2009). The Dutch species of Limnesia, with ecological and biological notes (Acari: Hydrachnidia: Limnesiidae). 
Nederlanse Faunistische Mededelingen, 30: 5374.

VIETS K (1930). Quantitative Untersuchungen über die Hydracarinen der noeddeutschen Seen. Arch. Hydrobiol., 12: 1-71.

VIETS K(1931). Tiefenverteilung eniger Hydracarinen in norddeutschen Seen. Zool. Anz., 96: 276-282.

VIETS K (1936). Spinnentiere oder Arachnoidea. VII: Wassermilben oder Hydracarina. Tierwelt Dtschl. 31: 1-288, 32: 289-374.

ZAWAL A (1992). Water mites (Hydracarina) of three small lakes in the neighbourhood of Poznań. Acta Hydrobiol., 34: 157-174.

ZAWALA(2006). Materiały do znajomości wodopójek (Acari: Hydrachnidia) okolic Złocieńca (północno-zachodnia Polska). Acta Biologica, 13: 163-169.

ZAWAL A (2007). Wodopójki (Hydrachnidia) rezerwatu ,Jezioro Szare” i jego otuliny. Par. Nar. Rez. Przyr., 26(4): 57-78.
ZAWAL A (2009). Nowe stanowisko Crocothemis erythraea (Brullé, 1832) w Polsce zachodniej. Odonatrix 6: 6-8.

ZAWAL A \& STĘPIEŃ E (2007). Charakterystyka fizyko-chemiczna wód rezerwatu „Jezioro Szare” oraz ocena jego podatności na degradację. Par. Nar. Rez. Przyr. 26(4): 3-19.

Zawal A, StęPIEŃ E, Szlauer-Łukaszewska A, MiCHOŃSKI G, KŁOSOWSKA M, BAŃKOWSKA A, MYŚLIWY M, STRYJECKI R, BUCZYŃSKA E \& BUCZYŃSKI P (2015). The influence of dredging of a lowland river (the Krapiel in NW Poland) on water mite fauna (Acari: Hydrachnidia), 186: 217-232. http://dx.doi.org/10.1127/fal/2015/0735

Received: March 20th, 2014

Accepted: June 1st, 2015

Branch editor: Stuart Halse 